\title{
Ecophysiological Responses of White Clover - Hybrid Ryegrass Mixture to Foliar Fertilisation
}

\author{
Daniel DUNEA ${ }^{1}$, Loredana Beatrice NEAGU FRĂSIN ${ }^{1 *}$, Niculae DINCĂ ${ }^{2}$ \\ ${ }^{1}$ Valabia University of Targoviste, Faculty of Environmental Engineering and Food Science, 18-24Unirii Blvd,, B1, Targoviste, Romania; ddunea@yahoo.com; \\ loredana_beatrice2003@yahoo.com (*correspondingauthor) \\ ${ }^{2}$ University of Agronomic Sciences and Veterinary Medicine Bucharest, Faculty of Agriculture, 59 Mărăști Blvd., Sector 1, Bucharest, Romania; nicudinca@yahoo.com
}

\begin{abstract}
The rationale of the study was to check whether the association of hybrid ryegrass with white clover owing a moderate competition capacity, and optimal foliar fertilization will provide high and stable yields by reducing conventional fertilization rates. The experiment was carried out during two years of cropping with six growth cycles in a randomized block design with three replicates in Targoviste Piedmont Plain, South of Romania. In the first year, the plots received no nitrogen fertilisers in order to allow the biological potential development. In the second year, foliar fertilisation was applied six times in the fertilised variants during the vegetation season. The comparison between the six growth cycles showed that the biological potential of white clover in pure stand without foliar fertilisation was higher in the first cropping year than in the second one. Application of foliar fertilisation treatments enhanced the competition capacity of the hybrid ryegrass in the first production cycle of the second year. In white clover pure stand, the fertilisation increased the assimilatory areas from 3.6 to 4.8 ( $p<0.05$ ). The contribution of hybrid ryegrass to the cumulative Leaf Area Index of species in the binary mixture was significant (4.7 no fertilisation; 4.9 foliar fertilisation), which revealed a low competition capacity of white clover in mixture ( 0.69 no fertilisation; 1.03 foliar fertilisation). In white clover-hybrid ryegrass mixtures, foliar fertilisation showed benefits in the first two growth cycles according to the phenophase particularities and weather conditions.
\end{abstract}

Keywords: leaf measurements, grass/clover swards, herbage yield, plant competition, radiation use efficiency

\section{Introduction}

In pure stand, the high yielding species of grasses such as hybrid ryegrass, orchard grass or tall fescue consume important quantities of nitrogen along with other nutrients. The use of conventional fertilizers ensures a proper balance for obtaining the envisaged forage yield gain and for maintaining the equilibrium of nutrients in soil (Zheng et al., 2013). However, the use of substantial fertilizer inputs in intensive forage systems has often determined negative impacts on the groundwater (Stuart et al., 2011). The application of foliar fertilizers on plants' foliage reduces the risk of water pollution with nitrates due to the small quantities used in optimal fertilization schemes, as well as through the consumption stimulation of excess nutrients existing in the soil (Crews and Peoples, 2004). These fertilizers should be used only as a complement to obtain forage yield gains and should not be used exclusively to avoid soil depletion or degradation in short time (Dunea and Dincă, 2014).

Nitrogen $(\mathrm{N})$ influences plant growth by increasing leaf area and hence carbon assimilation (Cui et al., 2014). The process depends on the enzymes activity in chloroplasts. Chloroplasts contain up to $75 \%$ of the leaf tissues' nitrogen in plants with C3 photosynthesis (Chapin et al., 1987). Nitrogen fertilisation in high supplies determines a negative effect on clover species, because this element positively influences the crop performances of perennial grasses enhancing their light interception and absorption (Gatti et al., 2013). Annicchiarico and Tomasoni (2010) found that, without N fertilisation, mixtures out-yielded white clover and grass pure stands. With $\mathrm{N}$ fertilisation at double rate to pure grass, yields from mixtures were greater than from clover and comparable to Italian ryegrass. A decrease in the leaf nitrogen levels from top to bottom of the canopy was observed in many forage crops (Xiaohong et al., 2011). The modifications of light interception profile positively correlate with this phenomenon. Leaf area index is the essential determinant of the solar radiation interception of pure stands (Fletcher $e t$ al., 2013). Nitrogen availability has a substantial effect on the light use efficiency of perennial grasses in phytosociological associations (Dunea and Motcă, 2007; Den Hollander et al., 2007; Lantinga et al., 1999).

The rationale of the study was to check whether the association of hybrid ryegrass (Lolium hybridum Hausskn.) with a legume species owing a moderate competition capacity i.e. white clover (Trifolium repens L.), and optimal foliar 
174

fertilization will provide high and stable yields by reducing conventional fertilization rates. The role of white clover in the mixture was to fix the symbiotic nitrogen favouring the fast growth and development of hybrid ryegrass in the first growth cycle of the vegetation season. Clover contribution to the total biomass yield increases in the next cycles during two years of cropping. Further expected benefits are the increasing of overall forage quality and digestibility (Phelan et al., 2013; Malinowski et al., 2012).

The research sought to characterize and optimize the agronomic performance during two years of cropping, considered economically viable, of the following forage systems: white clover pure stand, hybrid ryegrass pure stand, and white clover-hybrid ryegrass binary mixture (50\%:50\%). The focus of the study was to establish the effects of complex foliar fertiliser application $\left(\mathrm{N}_{15} \mathrm{P}_{5} \mathrm{~K}_{30}+3 \mathrm{MgO}\right)$ on the relevant ecophysiological characteristics (e.g., radiation use efficiency, leaf area index, dry matter etc.) of the species in the second vegetation season on the soil and weather conditions of the Targoviste Piedmont Plain, South of Romania. The experiment was conducted during 2004-2005, the second cropping year presenting the highest precipitations amount recorded between 1961 and 2014. The present study quantified the effect of these unusual weather conditions on growth characteristics of species.

\section{Materials and methods}

The experiment was carried out on plots in a randomized block design with three replicates in Targoviste Piedmont Plain - South of Romania (i.e. Dobra village: N $44^{\circ} 46^{1} .905$, E $25^{\circ} 43^{1} .045,179-\mathrm{m}$ a.s.l.) during two cropping years (2004-2005) due to the fact that hybrid ryegrass is a biennial species. The soil was pseudogleic brown alluvial $(\mathrm{pH}-5.6$; humus - 3.51; Nitrogen index - 2.50; mobile $\mathrm{P}_{2} \mathrm{O}_{5}-3.9 \mathrm{ppm}$; and mobile $\mathrm{K}_{2} \mathrm{O}$ $-117 \mathrm{ppm}$, in the ocric horizon).

The annual average temperature $\left(9.3^{\circ} \mathrm{C}\right)$ in the second year (i.e. 2005) was the lowest of the $1995-2005$ interval $\left(10.29^{\circ} \mathrm{C}\right.$ multiannual average). Available Photosynthetically Active Radiation (PAR) during the vegetation season of 2005 was lower than 2004 due to the accentuated nebulosity occurred in May, June, and July (Fig.1). The weather data of the 2004 vegetation season showed a rainfall regime closed to the normal of the region (205.4 mm in March-May, $213.7 \mathrm{~mm}$ in June-July and $111.4 \mathrm{~mm}$ in August-September). In comparison with 2004, the annual rainfall sum of 2005 exceeded $1000 \mathrm{~mm}$, being the highest amount recorded between 1961 and 2014. The multiannual average of rainfalls recorded in Targoviste Plain between 1995 and 2004 was $474.69 \mathrm{~mm}$. Rainfalls recorded in 2005 vegetation season were significant as follows: $308.8 \mathrm{~mm}$ in March-May, $283.7 \mathrm{~mm}$ in June-July and $448.7 \mathrm{~mm}$ in AugustSeptember (fig. 2).

The 'Karina' white clover cultivar was tested in pure culture and in binary mixture (50:50) with the hybrid ryegrass ('Zefir' tetraploid cultivar) in a randomized block design with four replicates. 'Karina' is a diploid cultivar with rich foliage having broad leaflets; it is persistent in pure stand and resistant to diseases and pests. 'Zefir' is a Romanian cultivar which optimally combines the production and quality characteristics of Italian ryegrass with the lateness, grazing suitability, winter resistance, and persistence characteristics of perennial ryegrass.
The plots were sown to ensure an optimal density $(20 \mathrm{~kg}$ ha $\left.{ }^{1}\right)$ on April 24, 2004 in plots of $3 \mathrm{~m} \times 5 \mathrm{~m}$. Three forage cuttings were performed each year; $\mathrm{C} 1, \mathrm{C} 2$, and $\mathrm{C} 3$ were the abbreviations for the growth cycles in 2004 until cutting dates, respectively C4, C5, and C6 for the year 2005 (Fig. 1).

In the first year, the plots received no nitrogen fertiliser to allow the biological potential development. In the second year, the foliar fertilisation was applied six times in the fertilised $(\mathrm{Ft})$ variants during the vegetation season (Fig. 1). The selected formula for foliar fertilisation was $\mathrm{N}_{15} \mathrm{P}_{5} \mathrm{~K}_{30}+3 \mathrm{MgO}$ using an approved commercial product. The selection criteria took into account the physicochemical properties of the soil (low phosphorous supply), the possibility of fractional application of fertiliser, and the facilitation of foliar nutrients and microelements absorption resulting from the quasi-horizontal position of the foliage in the clover canopy. The chemical composition of the fertiliser was Nitrogen $(\mathrm{N})-15 \%$; Nitrate-N $\left(\mathrm{NO}_{3}^{-}\right)-11.3 \%$; Ammonia- $\mathrm{N}\left(\mathrm{NH}_{4}^{+}{ }_{4}\right)-3.7 \% ; \mathrm{P}_{2} \mathrm{O}_{5}-5 \% ; \mathrm{K}_{2} \mathrm{O}$ $-30 \%$; $\mathrm{MgO}-3 \%$; B - 0.025; Mo - 0.004; and chelates: $\mathrm{Cu}$ EDTA - 0.010; Fe EDTA - 0.070; Mn EDTA - 0.040; Zn EDTA - 0.075 .

Homogeneous foliage sprayings $\left(2.5 \mathrm{~kg} \mathrm{ha}^{-1}\right)$ were performed at 49,70 and 91 DAR (Days After Regrowth) in C4; 119 and 147 DAR in C5, respectively 189 DAR in C6 (Fig.1).

The eco-physiological aspects of the extra-radicular absorption were carefully analysed in order to adapt the method of foliar fertilisation to uniform and to heterogeneous canopies. The uniform distribution of the foliar fertiliser within the canopy was dependent on the leaf area distribution, the height and density of the assimilatory surfaces, respectively. In the mixture, the hybrid ryegrass exceeded the white clover plants' height early in C4. The height difference between the two species resulted in difficulties when applying foliar fertiliser at 91 DAR (third treatment), which we compensated by spraying plants on two height units: over the top of mixed canopy $(65 \mathrm{~cm})$, and at the average height of white clover $(34 \mathrm{~cm})$. The $\mathrm{C} 5$ and $\mathrm{C} 6$ growth cycles did not encounter such impediments, as the periods of hybrid ryegrass exceeding clover height were much shorter.

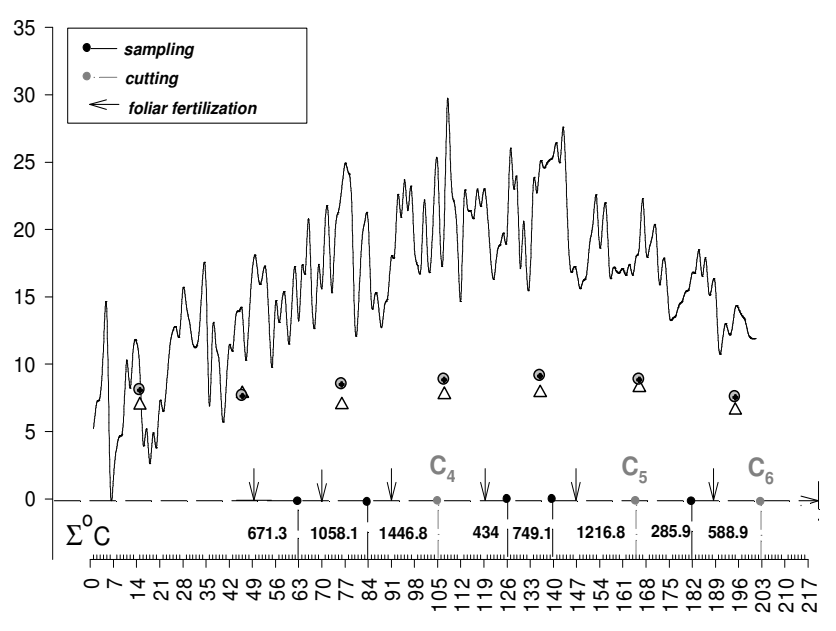

Week scale

Fig. 1. Daily average temperatures and accumulated heat units $\left({ }^{\circ} \mathrm{C}\right)$ in 2005, and monthly average of PAR (MJ.m-2 $)$ in 2004 (circles) and 2005 (triangles); C4, C5 and C6 - cutting moments in 2005; $\mathrm{N}_{15} \mathrm{P}_{5} \mathrm{~K}_{30}+3 \mathrm{MgO}$ foliar fertilisation application (arrows) 


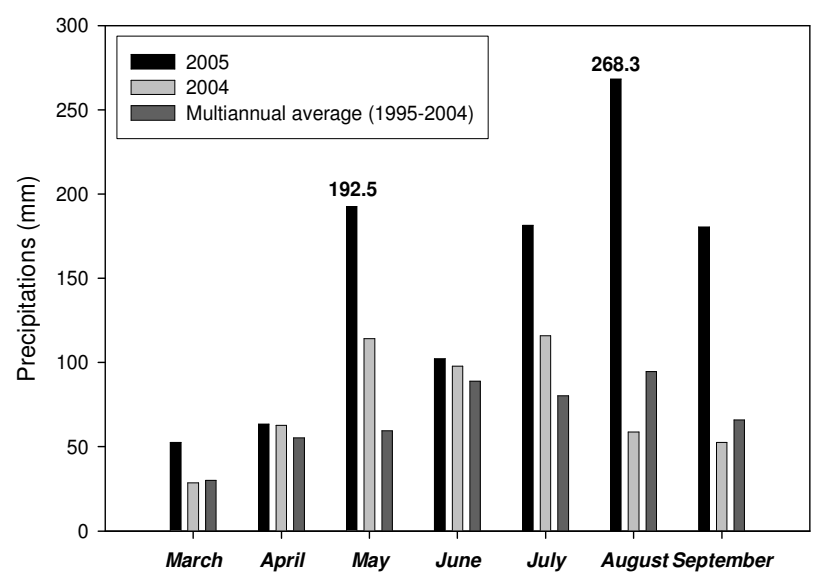

Fig. 2 Monthly average of precipitations $(\mathrm{mm})$ in the vegetation seasons and on multiannual scale in Targoviste Piedmont Plain, South of Romania

Samples were collected once every two weeks using a $50 \times 50$ $\mathrm{cm}$ frame from 2 representative points on the diagonal of each plot. The harvested material was separated into morphological components in pure stands and for each species in mixtures. The samples were dried at $105^{\circ} \mathrm{C}$ for $24 \mathrm{~h}$ and weighted using a precision balance. The leaf area index (LAI) was established by using a Li-cor 3100 Leaf-Area Meter ${ }^{\circledR}$ (Li-Cor Inc., Lincoln, NE, U.S.A.). At each cutting, the harvested green mass was weighed from each control plot immediately after harvest.

On-site microclimate monitoring was performed by using a WS-GP1 Delta-T Devices Automatic Weather Station, which provided PAR, air and soil temperature, rainfall parameters, and relative humidity. The data were associated with the meteorological data obtained from Targoviste meteorological station (WMO id 153750) to compare with the local weather conditions of Targoviste Piedmont Plain.

The determined morphophysiological variables were the following: dry matter accumulation (DM), relative growth rate (RGR), leaf area index (LAI), leaf area ratio (LAR), specific leaf area (SLA), leaf weight ratio (LWR), net assimilation rate (NAR), and radiation use efficiency (RUE).

The application of the multiple comparison tests (Tukey Honestly Significant Differences) allowed the statistical significance estimation of the fertilisation scheme, cropping system, and weather factors influence on the eco-physiological characteristics of the white clover in pure stand and in mixture with hybrid ryegrass, and the response to foliar fertilisation.

\section{Results and discussions}

The experimental results provided detailed information regarding the dynamics of changes in the evolution of dry matter accumulation for each growth cycle, and hybrid ryegrass and white clover LAIs, required in the description of the interspecific competition for light in the mixed canopy. The descriptive characterization regarding the dry matter accumulation of each growth cycle $(\mathrm{C} 4, \mathrm{C} 5$ and $\mathrm{C} 6)$ of the second vegetation season allowed the estimation of the intrinsic interrelations between foliar fertilisation treatments and eco-physiological responses of the species in pure stand and in mixture.

\section{Influence of foliar fertilisation on the bioconversion efficiency of thespecies}

The white clover-hybrid ryegrass mixture showed higher yield increments, compared to both pure stand fertilised variants and the ones with no fertilisation treatment. The distribution of dry matter production efficiency on growth cycles in white clover pure stand without fertilisation (Mt) was 367 (C4), 198 (C5), and $115 \mathrm{~g} \mathrm{DM} \mathrm{m}^{-2}(\mathrm{C} 6)-6.8 \mathrm{t} \mathrm{DM} \mathrm{ha}^{-1} \mathrm{y}^{-1}$, while the foliar fertilised variants $(\mathrm{Ft})$ recorded $426(\mathrm{C} 4), 258(\mathrm{C} 5)$ and $149 \mathrm{~g}$ $\mathrm{DM} \mathrm{m}^{-2}(\mathrm{C} 6)-8.3 \mathrm{t} \mathrm{DM} \mathrm{ha} \mathrm{a}^{-1} \mathrm{y}^{-1}$. In the Mt mixture, total DM accumulation was 750 (C4), $424(\mathrm{C} 5)$, and $167 \mathrm{~g} \mathrm{DM} \mathrm{m}^{-2}$ (C6) $-13.4 \mathrm{t} \mathrm{DM} \mathrm{ha}{ }^{-1} \mathrm{y}^{-1}$, while $\mathrm{Ft}$ variants produced $966(\mathrm{C} 4), 578$ (C5), and $180 \mathrm{~g} \mathrm{DM} \mathrm{m}^{-2}$ (C6) - 17.2 t DM ha ${ }^{-1} \mathrm{y}^{-1}$ (Table 1). The first two cuttings $(\mathrm{C} 4+\mathrm{C} 5)$ provided 83.14 to $89.57 \%$ from the total annual yield of dry matter in the second year, which corresponded to the percentages presented by Frame $e t a l$. (1998), i.e. 80-90\% at the harvests in June and early August.

\section{Forage yield of white clover in purestand}

The first growth cycle (C4) in the second year of the experiment lasted approximately 105 days from the regrowth of species in spring to the cutting moment (March 13 - June 25, 2005) and was less productive than $\mathrm{Cl}$ cycle for both Mt and Ft variants. The allocation of white clover dry matter in the aboveground morphological components in pure stand showed a distinct significant increase of the foliage mass as a result of $\mathrm{N}_{15} \mathrm{P}_{5} \mathrm{~K}_{30}+3 \mathrm{MgO}$ foliar fertilisation treatment $\left(+53.4 \mathrm{~g} \mathrm{DM} \mathrm{m}^{-2}\right.$ leaves $-\mathrm{p}<0.01)$, but the stems, stolons and petioles quantity remained almost constant. In the Mt variant, white clover produced $246.48 \mathrm{~g} \mathrm{DM} \mathrm{m}^{-2}$ stems, petioles and stolons, $114.6 \mathrm{~g}$ $\mathrm{DM} \mathrm{m}^{-2}$ leaves and $6 \mathrm{~g} \mathrm{DM} \mathrm{m}^{-2}$ heads and buds. The sequential fertilisation improved the increasing of the biomass for all the components, as follows: $248.4 \mathrm{~g} \mathrm{DM} \mathrm{m}^{-2}$ stems, petioles and stolons, $168 \mathrm{gDM} \mathrm{m}^{-2}$ leaves and $9.6 \mathrm{gDM} \mathrm{m}^{-2}$ heads and buds.

Table 1. Dry matter accumulation in the experiment performed in Targoviste Piedmont Plain, South of Romania

\begin{tabular}{|c|c|c|c|c|c|c|}
\hline Variant & White clover & $\begin{array}{l}\text { White clover + } \\
\text { Hybrid ryegrass }\end{array}$ & $\begin{array}{c}\text { White } \\
\text { clover } \\
\text { Mt }\end{array}$ & $\begin{array}{c}\text { White } \\
\text { clover } \\
\text { Ft }\end{array}$ & $\begin{array}{c}\text { White clover + } \\
\text { Hybrid } \\
\text { ryegrass } \\
\text { Mt }\end{array}$ & $\begin{array}{c}\text { White clover + } \\
\text { Hybrid } \\
\text { ryegrass } \\
\text { Ft } \\
\end{array}$ \\
\hline Year & \multicolumn{2}{|c|}{2004} & \multicolumn{4}{|c|}{2005} \\
\hline $1^{\text {st }}$ cutting $\left(\mathrm{g} \mathrm{m}^{-2}\right)$ & 486.4 & 650.8 & 367 & 426 & 750 & 966 \\
\hline $2^{\text {nd }}$ cutting $\left(\mathrm{g} \mathrm{m}^{-2}\right)$ & 195.8 & 564.9 & 198 & 258 & 424 & 578 \\
\hline $3^{\text {rd }}$ cutting $\left(\mathrm{g} \mathrm{m}^{-2}\right)$ & 108 & 257.7 & 115 & 149 & 167 & 180 \\
\hline Total DM $\left(t\right.$ ha $\left.^{-1} \mathrm{y}^{-1}\right)$ & 7.9 & 14.7 & 6.8 & 8.3 & 13.4 & 17.2 \\
\hline
\end{tabular}

Mt - not fertilised

$\mathrm{Ft}$ - foliar fertilisation $\left(\mathrm{N}_{15} \mathrm{P}_{5} \mathrm{~K}_{30}+3 \mathrm{MgO}\right)$ 
Table 2. Effect of foliar fertilisation $\left(\mathrm{N}_{15} \mathrm{P}_{5} \mathrm{~K}_{30}+3 \mathrm{MgO}\right)$ on dry matter accumulation of white clover and hybrid ryegrass in the binary mixture (50:50)

\begin{tabular}{ccccc}
\hline Indicator & Unit & C4 & C5 & C6 \\
\hline Total Dry Weight - Mt $C_{n}$ & $\left(\mathrm{~g} \mathrm{DM} \mathrm{m}^{-2}\right)$ & 750 & 424.06 & 166.8 \\
Total Dry Weight - Ft $C_{n}$ & $\left(\mathrm{~g} \mathrm{DM} \mathrm{m}^{-2}\right)$ & 965.76 & 578 & 179.8 \\
Dry Weight Gain & $\left(\mathrm{g} \mathrm{DM} \mathrm{m}^{-2}\right)$ & $215.76^{* *}$ & $153.94^{* * *}$ & 13 \\
$C_{n}$ Ft $-C_{n}$ Mt & $(\%)$ & 28.77 & 36.3 & 7.2 \\
Total Dry Weight $-C_{m}$ & $\left(\mathrm{~g} \mathrm{DM} \mathrm{m}^{-2}\right)$ & 650.8 & 564.9 & 275.7 \\
$C_{n}$ Mt $-C_{m}$ Difference & $\left(\mathrm{g} \mathrm{DM} \mathrm{m}^{-2}\right)$ & $99.2^{*}$ & $-140.84^{* * *}$ & $-108.9^{* *}$ \\
$C_{n} \mathrm{Ft}-C_{m}$ Difference & $\left(\mathrm{g} \mathrm{DM} \mathrm{m}^{-2}\right)$ & $305.96^{* *}$ & 13.1 & $-95.9^{*}$ \\
\hline
\end{tabular}

$\mathrm{Mt}$ - not fertilised; $\mathrm{Ft}$ - foliar fertilised; $C_{n}=C 4, C 5$, C6 - growth cycles of the second cropping year;

$C_{m}=C 1, C 2$, C3; Multiple comparison using Tukey HSD test $\left({ }^{* * *} \mathrm{p}<0.001 ;{ }^{* *} \mathrm{p}<0.01 ;{ }^{*} \mathrm{p}<0.05\right)$, DL - difference limit.

Table 3. Effect of foliar fertilisation $\left(\mathrm{N}_{15} \mathrm{P}_{5} \mathrm{~K}_{30}+3 \mathrm{MgO}\right)$ on foliage characteristics of white clover cv. 'Karina' in pure stand and in mixture with hybrid ryegrass recorded in C4 growth cycle (105DAR - days after regrowth)

\begin{tabular}{|c|c|c|c|c|c|c|}
\hline \multirow{2}{*}{ Pure stand } & LAI Mt & LAI Ft & LAR Mt & LAR Ft & LWR Mt & LWR Ft \\
\hline & $\left(\mathrm{m}^{2} \mathrm{~m}^{-2}\right)$ & $\left(\mathrm{m}^{2} \mathrm{~m}^{-2}\right)$ & $\left(\mathrm{m}^{2} \mathrm{~kg}^{-1} \mathrm{D} . \mathrm{W}\right)$ & $\left(\mathrm{m}^{2} \mathrm{~kg}^{-1} \mathrm{D} . \mathrm{W}\right)$ & $\left(\mathrm{g} \mathrm{g}^{-1}\right)$ & $\left(\mathrm{g} \mathrm{g}^{-1}\right)$ \\
\hline \multirow{4}{*}{ Mixture } & 3.63 & $4.87^{*}$ & 11.44 & $9.90^{* *}$ & 0.46 & 0.48 \\
\hline & & DL 5\%- 1.22 & & DL $1 \%-1.39$ & & DL $5 \%-0.07$ \\
\hline & $\begin{array}{l}\text { LAI C Mt } \\
\left(\mathrm{m}^{2} \mathrm{~m}^{-2}\right)\end{array}$ & $\begin{array}{l}\text { LAI R Mt } \\
\left(\mathrm{m}^{2} \mathrm{~m}^{-2}\right)\end{array}$ & $\begin{array}{c}\mathrm{LAI}(\mathrm{C}+\mathrm{R}) \mathrm{Mt} \\
\quad\left(\mathrm{m}^{2} \mathrm{~m}^{-2}\right)\end{array}$ & $\begin{array}{l}\text { LAI C Ft } \\
\left(\mathrm{m}^{2} \mathrm{~m}^{-2}\right)\end{array}$ & $\begin{array}{l}\text { LAI R Ft } \\
\left(\mathrm{m}^{2} \mathrm{~m}^{-2}\right)\end{array}$ & $\begin{array}{c}\text { LAI }(\mathrm{C}+\mathrm{R}) \mathrm{Ft} \\
\quad\left(\mathrm{m}^{2} \mathrm{~m}^{-2}\right)\end{array}$ \\
\hline & 0.69 & 4.70 & 5.39 & 1.03 & 4.97 & $6.00^{*}$ \\
\hline
\end{tabular}

LAI - leaf area index, LAR - leaf area ratio, and LWR - leaf weight ratio; (Mt - not fertilised; Ft - foliar fertilised; C - white clover; R - hybrid ryegrass); Multiple comparison using Tukey HSD test $\left({ }^{* * *} \mathrm{p}<0.001 ;{ }^{* *} \mathrm{p}<0.01 ;{ }^{*} \mathrm{p}<0.05\right)$.

The effect of foliar fertilisation on the total yield obtained per unit area $\left(\mathrm{m}^{2}\right)$ showed the absence of statistical significance regarding the increment of $58.92 \mathrm{~g} \mathrm{DM}$ compared to the $\mathrm{Mt}$ variant in the edaphic and ecoclimatic conditions of the trial experiments. The comparison between the first growth cycles (C4 and C1) showed that the biological potential of white clover was higher in the first cropping year than in the second one for this specific period; its phenotypic expression was the high dry weight quantity as compared to $\mathrm{Mt}(\mathrm{p}<0.05)$ and Ft variants.

In the second growth cycle (C5: June 25 - August 23, 2005 -59 days after $\mathrm{C} 4)$, the effect of foliar fertilisation application on DM accumulation was distinctly significant $(\mathrm{p}<0.01)$ for the Mt-Ft difference $\left(+61.82 \mathrm{~g} \mathrm{DM} \mathrm{m}^{-2}-\mathrm{DL} 1 \%= \pm 59.42\right)$, gaining $23.75 \%$.

The retrospective analysis of forage productivity showed significant differences $(\mathrm{p}<0.05)$ between $\mathrm{C} 5(\mathrm{Ft})$ and $\mathrm{C} 2(\mathrm{Mt})$ recorded in the white clover pure stands $\left(+64.42 \mathrm{gDM} \mathrm{m}^{-2}\right)$ and not significant between $\mathrm{C} 5(\mathrm{Mt})$ and $\mathrm{C} 2(\mathrm{Mt})$.

In the final growth cycle (C6), which lasted 39 days after $\mathrm{C} 5$ cutting (August 23 - September 30), a single application of foliar fertiliser was performed two weeks before the last cutting. The white clover response to the foliar fertilisation $(p<0.001)$ provided an additional $33.8 \mathrm{~g} \mathrm{DM} \mathrm{m}^{-2}(\mathrm{DL} 1 \%= \pm 17.34)$, representing $29.47 \%$ gain compared to the unfertilised variants.

\section{Forage yield of white clover-hybrid ryegrass mixture}

The influence of foliar fertilisation on dry matter accumulation of the associated species in C4 resulted in a significant increase of $215.76 \mathrm{~g} \mathrm{DM} \mathrm{m}^{-2}(28.77 \%)$ compared to the Mt variant (Table 2).

Following the foliar fertilisation treatments, white clover contribution increased with $2.22 \%$, while the hybrid ryegrass showed an overall vigorous competition capacity, its percentage to the total aboveground biomass being $78.9 \%$.

In the next growth cycle (C5), the difference between the total dry matter of the $\mathrm{Ft}$ and $\mathrm{Mt}$ mixture was $153.94 \mathrm{~g} \mathrm{DM} \mathrm{m}^{-2}$ $1+36.3 \%(\mathrm{p}<0.001)$. However, the forage yield recorded for the
Mt variant in this cycle was lower (-140.84g) than the dry matter accumulated in C2 without fertilisation $(\mathrm{p}<0.001)$. Foliar fertilisation ensured a compensation of the biological efficiency diminishing the hybrid ryegrass, which exceeded the dry matter of the corresponding cycle in the first year with $13 \mathrm{~g} \mathrm{DM} \mathrm{m}^{-2}$ (DL 5\% = \pm 68.56 ). The explanation of lower productivity in that cycle also relied on the influence of the weather condition, especially the excessive rainfall regime. Foliar fertilisation had little influence in the last growth cycle (C5), showing a Ft-Mt difference of $13 \mathrm{gDM} \mathrm{m}^{-2}$.

The dry matter accumulations of both variants were significantly lower than in the $\mathrm{C} 3$ period of the previous year, due to the slow growth and development of the hybrid ryegrass (Table 2).

\section{The effects of foliar fertilisation on foliage characteristics}

The evolution of the cumulative leaf growth followed a sigmoidal shaped curve, the rate of the process decreasing in intensity towards maturity. Leaf number, leaf areas and positions on the plant determined modifications of the LAI. Leaf area distribution in the mixture was asymmetric, following a triangular shape, white clover having the maximum leaf area positioned in the lower third of the total height of the canopy (25-31\%), and ryegrass between 38 and $45 \%$.

Foliar fertilisation applied in the $\mathrm{C} 4$ growth cycle increased the assimilatory areas of the white clover in pure stand $(\mathrm{p}<0.05)$. The fertilised variants showed higher LAIs $\left(+1.29 \mathrm{~m}^{2} \mathrm{~m}^{-2}\right.$; DL $5 \%= \pm 1.22)$, compared to the unfertilised variants. The leaf area ratio (LAR), which is a morphological indicator of the plant leafiness, presented a statistical significant decrease $\left(-1.54 \mathrm{~m}^{2} \mathrm{~kg}^{-1}\right.$, DL $1 \%= \pm 1.39$ ), which suggested an increase in the weight of leaves, positively correlated with the leaf area development as a favourable response to the fertilisation system. LWR had a difference of $0.02(p>0.05)$ between the Mt and Ft variants (Table 3). Consequently, white clover showed positive responses of the foliage characteristics to the foliar fertilisation stimuli in the first growth cycle of the second cropping year. 
In the white clover-hybrid ryegrass mixture, white clover did not show the same clear increase in the leaf area observed in pure stand, as a response to foliar fertilisation. The contribution of hybrid ryegrass to the cumulative LAI of species in the binary mixture was significant ( 4.7 in $\mathrm{Mt} ; 4.97 \mathrm{in} \mathrm{Ft}$ ), which revealed a low competition capacity of white clover in association (0.69 in $\mathrm{Mt} ; 1.03$ in Ft). However, at $105 \mathrm{DAR}$ in pure stand, white clover had higher LAIs of 3.63 in Mt and 4.87 in Ft variant.

Other experiment (Den Hollander et al., 2007) reported LWR values of $0.44-0.45$ at 75 days after sowing (DAS), LAI values between 4.2 and 4.6 at 82 DAS, and SLA values of 312.5-328.2 for two white clover cultivars (large leaved; Aran, and medium leaved; Riesling) in pure stands. These results were in agreement with our findings.

\section{The effects offoliarfertilisation on the Radiation Use Efficiency}

The RUE values emphasize the particularities of solar energy bioconversion to forage yield (Monteith, 1977). Pure stands of white clover showed a mean RUE value of $1.03 \mathrm{~g} \mathrm{DM} \mathrm{MJ}^{-1} \mathrm{~m}^{-2}$, and with foliar fertiliser treatments, this indicator increased to $1.20 \mathrm{gDMMJ}^{-1}$ $\mathrm{m}^{-2}$ at the first cutting of the second year. The same effect of fertilisation was also observed at the second growth cycle, RUE increasing by $0.28 \mathrm{~g} \mathrm{DM} \mathrm{MJ}^{-1} \mathrm{~m}^{-2}(\mathrm{DL} 1 \%= \pm 0.27)$, i.e. from 0.92 to $1.2 \mathrm{~g} \mathrm{DM} \mathrm{MJ}^{-1} \mathrm{~m}^{-2}$. In the third cycle, the increase was 0.26 (DL $1 \%= \pm 0.16)$, i.e. from 0.88 to $1.14(\mathrm{p}<0.01)$.

The experimentally confirmed response of white clover to foliar fertilisation stimuli allowed the assessment of the foliar fertilisers' effect on RUE and thus the biological efficiency of the species in uniform canopies. The application of foliar fertilisation in the second and third growth cycles appeared to have a significant influence on the increasing of white clover bioconversion of energy; this suggested that, from the feasibility point of view, this type of fertiliser should be applied in the last two regrowth cycles. In the mixed canopy, the efficiency of PAR utilization was particularly dependent on the dynamics of species' participation to the total yield per area unit in various phenophases of the vegetation season. The superior competition capacity of the hybrid ryegrass was the most influencing factor in the foliar fertilised variants during the $\mathrm{C} 4$ cycle. The interspecific competition inhibited the growth and development of white clover, while hybrid ryegrass reached higher RUEs of 1.71 $(\mathrm{Mt})$ and $2.15 \mathrm{gDMMJ}^{-1}(\mathrm{Ft})$. Its capacity diminished considerably in the next two growth cycles.

The results observed in the mixture for white clover $(0.4$ not fertilised, and $0.57 \mathrm{gDM} \mathrm{MJ}^{-1}$ foliar fertilised) and for hybrid ryegrass corresponded to the previous observations. Nassiri (1998) found that the RUEs of the 'Alice' variety were 0.53 (without nitrogen - N) and $0.55 \mathrm{~g} \mathrm{DM} \mathrm{MJ}^{-1}$ (with $\left.150 \mathrm{~kg} \mathrm{Nha}^{-1}\right)$; for the perennial ryegrass (Lolium perenne L.), they were 1.95 (without $\mathrm{N}$ ) and $2.14 \mathrm{~g} \mathrm{DM}$ $M \mathrm{~J}^{1}(\mathrm{~N})$. In the mixture with 'Gwenda' variety, perennial ryegrass showed 1.86 (without $\mathrm{N}$ ) and $2.02 \mathrm{gDMM}^{-1}(\mathrm{~N})$ and white clover cultivar reached $0.54(\mathrm{~N})$ and $0.41 \mathrm{gDMMJ}^{-1}$ (without $\mathrm{N}$ ). In pure stand, RUEs (gDM MJ') were as follows: 1.02 - 'Alice' variety, 0.96 - 'Gwenda' variety, 1.13 (without N) and $1.68(\mathrm{~N})$ for ryegrass.

In Targoviste Piedmont Plain, the overall cumulative RUE of both species per unit area was higher than in the pure stands of species for both $\mathrm{Mt}$ and $\mathrm{Ft}$ variants. The radiative resources were captured and absorbed in a more efficient and complementary manner. Foliar fertilisation resulted in very significant increases ( $<<0.01$ ) of the RUE values from 2.11 to $2.72 \mathrm{~g} \mathrm{DM} \mathrm{MJ}^{-1}$ in C4 (DL $0.1 \%= \pm 0.47$ ) and in C5 from 1.97 to $2.69 \mathrm{~g} \mathrm{DM} \mathrm{M}^{-1}$ (DL $0.1 \%= \pm 0.41)$ and not significant in $\mathrm{C} 6$, from 1.28 to $1.38 \mathrm{~g} \mathrm{DM}$ $\mathrm{MJ}^{-1}(\mathrm{DL} 5 \%= \pm 0.58)$.

\section{Conclusions}

One of the methods that can maintain or further increase the presence and participation of white clover to the forage yield formation in mixtures with perennial grasses is the foliar fertilisation applied according to the phenophases, weather conditions and regrowth period requirements.

The adaptation of the foliar fertiliser application in the canopies must be performed using a simplified balance, both to the requirements of white clover and hybrid ryegrass in different phases of vegetation, and to the weather conditions influencing the ammonium nitrification and nitrate solubilisation. The fractional application of fertilisers allowed a better combination between mineral and organic elements, and a compensation of the application cost by using optimal amounts and spraying timings.

The comparison between the growth cycles of the two cropping years showed that the biological potential of white clover in pure stand without fertilisation was higher in the first cropping year at the first cutting $\left(4.8 \mathrm{t} \mathrm{DM} \mathrm{ha}^{-1}\right)$ that the corresponding cycle of the next vegetation season (4.2 $\mathrm{t} \mathrm{DM}$ $\left.\mathrm{ha}^{-1}\right)$, but the annual yield $\left(7.9 \mathrm{tDM} \mathrm{ha} \mathrm{DH}^{-1}\right)$, was lower than in the second year $\left(8.3 \mathrm{t}\right.$ DM ha $\left.{ }^{-1}\right)$. The dry matter accumulation of the binary mixture showed a higher total production per unit area $\left(17.2 \mathrm{tDM} \mathrm{ha}^{-1}\right)$ as compared with the first year of cropping $\left(14.7 \mathrm{t} \mathrm{DM} \mathrm{ha} \mathrm{a}^{-1}\right)$. The phenotypic expression of foliar fertilisation was the higher total dry weight quantity and superior LAI though the clover content was diminished.

Foliar fertilisation treatments enhanced significantly the competition capacity of hybrid ryegrass in the first production cycle of the second year. In white clover pure stand, such fertiliser type was efficient in the last two regrowth cycles. In the white clover-hybrid ryegrass mixture, foliar fertilisation brought benefits in the first two growth cycles, according to the phenophase particularities and weather conditions.

\section{References}

Annicchiarico P, Tomasoni C (2010). Optimizing legume content and forage yield of mown white clover - Italian ryegrass mixtures through nitrogen fertilisation and grass row spacing. Grass Forage Sci 65:220-226.

Cui X, Yan Q, Sun J, Xiao S, Xie F, Chen Y (2014). Research progress on nitrogen use and plant growth. Journal of Northeast Agricultural University (English Edition) 21(2):68-74.

Chapin FS, Bloom AJ, Field CB, Waring RH (1987). Plant responses to multiple environmental factors. BioScience 37:49-57.

Crews TE, Peoples MB (2004). Legume versus fertilizer sources of nitrogen: ecological tradeoffs and human needs. Agr Ecosyst Environ 102(3):279-297.

Den Hollander NG, Bastiaans L, Kropff MJ (2007). Clover as a cover crop for weed suppression in an intercropping design $\mathrm{I}$. Characteristics of several clover species. Europ J Agronomy 26:92103.

Dunea D, Dincă N (2014). Improving land utilization using intensive grass-clover mixtures in forage production systems. Rom Agric Res 31:1-12. 
178

Dunea D, Motcă Gh (2007). Forage quality assessments of red clover (Trifolium pratense L.) through near infrared spectroscopy. Scientific Papers Animal Science and Biotechnologies 40(1):274283.

Fletcher AL, Johnstone PR, Chakwizira E, Brown HE (2013). Radiation capture and radiation use efficiency in response to $\mathrm{N}$ supply for crop species with contrasting canopies. Field Crop Res 150 (20):126-134.

Frame J, Charlton JFL, Laidlaw AS (1998). Temperate Forage Legumes. CAB International, New York, $327 \mathrm{p}$.

Gatti ML, Ayala Torales AT, Cipriotti PA, Golluscio RA (2013). Leaf and tiller dynamics in two competing $\mathrm{C} 3$ grass species: influence of neighbours and nitrogen on morphogenetic traits. Grass Forage Sci 68(1):151-164.

Lantinga EA, Nassiri M, Kropff MJ (1999). Modelling and measuring vertical light absorption within grass-clover mixtures. Agr Forest Meteorol 96:71-83.

Malinowski DP, Belesky DP, Ruckle JM, Fedders JM (2012). Productivity and botanical composition of orchardgrass-white clover swards in a cool-temperate hill land region of the eastern United States. Grassland Science 58:188-200.
Monteith JL (1977). Climate and the efficiency of crop production in Britain. Phil Trans R Soc Lond Series B 281:277-294.

Nassiri MM (1998). Modelling interactions in grass-clover mixtures. PhD Diss, Wageningen Agricultural University.

Phelan P, Casey A, Humphreys J (2013). The effect of target postgrazing height on sward clover content, herbage yield, and dairy production from grass-white clover pasture. J Dairy Sci 96:15981611.

Stuart ME, Gooddy DC, Bloomfield JP, Williams AT (2011). A review of the impact of climate change on future nitrate concentrations in groundwater of the UK. Sci Total Environ 409(15):2859-2873.

Xiaohong Z, Guoxiang W, Fei Y (2011). Characteristics of growth, nutrient uptake, purification effect of Ipomoea aquatica, Lolium multiflorum, and Sorghum sudanense grown under different nitrogen levels. Desalination 273(2-3):366-374.

Zheng H, Li X, Wang Y, Yin X, Yan Q, Chen Y (2013). Nutrient status and dynamics of Trifolium spp. at different growing stages. Journal of Northeast Agricultural University (English Edition) 20(3):6-11. 